\title{
Interaction of Common Bacterial Blight Bacteria with Disease Resistance Quantitative Trait Loci in Common Bean
}

\author{
Robert W. Duncan, Shree P. Singh, and Robert L. Gilbertson
}

First and third authors: Department of Plant Pathology, University of California, Davis, One Shields Ave., Davis 95616; and second author: Plant, Soil and Entomological Sciences Department, University of Idaho, Kimberly Research \& Extension Center, 3793 North 3600 East, Kimberly 83341-5076.

Current address of R. W. Duncan: Department of Soil and Crop Sciences, Texas A\&M University, College Station 77843-2474.

Accepted for publication 27 October 2010.

\begin{abstract}
Duncan, R. W., Singh, S. P., and Gilbertson, R. L. 2011. Interaction of common bacterial blight bacteria with disease resistance quantitative trait loci in common bean. Phytopathology 101:425-435.

Common bacterial blight (CBB) of common bean (Phaseolus vulgaris L.) is caused by Xanthomonas campestris pv. phaseoli and X. fuscans subsp. fuscans, and is the most important bacterial disease of this crop in many regions of the world. In 2005 and 2006, dark red kidney bean fields in a major bean-growing region in central Wisconsin were surveyed for CBB incidence and representative symptomatic leaves collected. Xanthomonad-like bacteria were isolated from these leaves and characterized based upon phenotypic (colony) characteristics, pathogenicity on common bean, polymerase chain reaction (PCR) with X. campestris pv. phaseoli- and X. fuscans subsp. fuscans-specific primers, and repetitiveelement PCR (rep-PCR) and 16S-28S ribosomal RNA spacer region sequence analyses. Of 348 isolates that were characterized, 293 were identified as common blight bacteria (i.e., pathogenic on common bean and positive in PCR tests with the X. campestris pv. phaseoli- and X. fuscans subsp. fuscans-specific primers), whereas the other isolates were nonpathogenic xanthomonads. Most (98\%) of the pathogenic xanthomonads were $X$. campestris pv. phaseoli, consistent with the association of this bacterium with CBB in large-seeded bean cultivars of the Andean gene pool. Two types of $X$. campestris pv. phaseoli were involved with

yellow mucoid colonies, no brown pigment production, and a typical $X$. campestris pv. phaseoli rep-PCR fingerprint (60\% of strains); and a new phenotype and genotype ( $\mathrm{Px})$ with an $X$. campestris pv. phaseoli-type fingerprint and less mucoid colonies that produced brown pigment $(40 \%$ of strains). In addition, a small number of $X$. fuscans subsp. fuscans strains, representing a new genotype $(\mathrm{FH})$, were isolated from two fields in 2005. Representative $\mathrm{P}$ and $\mathrm{Px} X$. campestris pv. phaseoli strains, an FH $X$. fuscans subsp. fuscans strain, plus five previously characterized $X$. campestris pv. phaseoli and X. fuscans subsp. fuscans genotypes were inoculated onto 28 common bean genotypes having various combinations of known CBB resistance quantitative trait loci (QTL) and associated sequence-characterized amplified region markers. Different levels of virulence were observed for $X$. campestris pv. phaseoli strains, whereas $X$. fuscans subsp. fuscans strains were similar in virulence. The typical $X$. campestris pv. phaseoli strain from Wisconsin was most virulent, whereas $X$. campestris pv. phaseoli genotypes from East Africa were the least virulent. Host genotypes having the SU91 marker-associated resistance and one or more other QTL (i.e., pyramided resistance), such as the VAX lines, were highly resistant to all genotypes of common blight bacteria tested. This information will help in the development of CBB resistancebreeding strategies for different common bean market classes in different geographical regions, as well as the identification of appropriate pathogen genotypes for screening for resistance.
\end{abstract} CBB in this region: typical $X$. campestris pv. phaseoli $(\mathrm{P})$ isolates with
Common bacterial blight (CBB) is the most important bacterial disease of common bean (Phaseolus vulgaris L.) in many common bean-growing regions of the world. The disease is caused by Xanthomonas campestris pv. phaseoli Smith (Dye) (synonym: X. axonopodis pv. phaseoli (Smith) Vauterin et al.) and $X$. fuscans subsp. fuscans sp. nov. (10,45). Symptoms induced by $X$. campestris pv. phaseoli and $X$. fuscans subsp. fuscans are indistinguishable, and both bacteria can cause significant negative impact on yield and seed quality, especially in highly susceptible cultivars $(45,49)$. Common blight bacteria infect the foliage, pods, and seed and disease development is favored by warm, humid conditions $(45,48)$. The bacteria survive and spread with infected or contaminated seed but can also survive in association with plant debris and weeds $(10,12,38,45,46)$.

Results of genetic, phenotypic, and physiological studies have revealed that $X$. campestris pv. phaseoli and $X$. fuscans subsp. fuscans are distinct species $(1,5,6,10,11,23,25,34,47)$. Hostpathogen interaction studies have revealed that these bacteria

Corresponding author: R. Duncan; E-mail address: rduncan@tamu.edu

doi:10.1094/PHYTO-03-10-0095

(C) 2011 The American Phytopathological Society differ in their prevalence and virulence on genotypes of the two major common bean gene pools, with $X$. campestris pv. phaseoli most commonly associated with large-seeded Andean bean cultivars and $X$. fuscans subsp. fuscans associated with $\mathrm{CBB}$ in Andean and Middle-American bean cultivars. In addition, numerous studies have revealed that $X$. campestris pv. phaseoli strains show more genetic and pathogenic variability compared with the more homogeneous $X$. fuscans subsp. fuscans strains $(1,23,25,34,36)$. Three $X$. campestris pv. phaseoli genotypes were described by Mkandawire et al. (34) based upon repetitive-element polymerase chain reaction (rep-PCR) and pathogenic variability. One of these genotypes is represented by a large homogeneous group of $X$. campestris pv. phaseoli strains from New World (e.g., North and South America, Mexico, and the Caribbean) and Old World (e.g., Spain and Australia) locations (hereafter referred to as typical $X$. campestris pv. phaseoli strains), whereas the other genotypes are represented by strains from East Africa $(23,34)$. The East African strains were significantly more virulent on Andean than Middle-American genotypes, whereas no such differential virulence was observed for typical $X$. campestris pv. phaseoli strains. Two X. fuscans subsp. fuscans genotypes, one from the New World and one from the Old World, have been identified based on minor differences in the rep-PCR fingerprints; 
however, strains of these genotypes are similar in virulence on Andean and Middle-American genotypes.

Effective management of $\mathrm{CBB}$ requires an integrated pest management strategy beginning with pathogen-free seed, which is commonly produced in arid regions such as the western United States. Crop rotation and deep tillage are also important management strategies for CBB inoculum associated with bean debris and weeds in or around fields. However, the most effective and sustainable management strategy is host resistance. Unfortunately, little or no CBB resistance is present in most commercial common bean cultivars. Low to moderate levels of CBB resistance have been identified in a few common bean genotypes from the Middle-American gene pool, such as Great Northern (GN) Montana No. 5, whereas no resistance has been identified in the large-seeded Andean gene pool (49). The resistance quantitative trait loci (QTL) from GN Montana no. 5 and GN Nebraska no. 1, selection 27 has been associated with the SAP6 molecular marker (28). Moderate to high levels of CBB resistance have been introgressed into common bean breeding lines from scarlet runner bean $(P$. coccineus L.) $(33,39)$ and tepary bean $(P$. acutifolius A. Gray) $(27,40)$, respectively. This resistance is quantitative, and resistance QTL introgressed from $P$. acutifolius have been associated with the molecular markers SU91 (42) and BC420 (53). The presence of these markers in common bean breeding lines, such as XAN 159, has been associated with high levels of CBB resistance (51).

Despite the availability of CBB resistance QTL and associated markers, only low levels of $\mathrm{CBB}$ resistance have been introgressed into common bean cultivars of any market class $(31,32)$. This may be due, in part, to the fact these markers are linked with undesirable traits, including low yield and undesirable seed size or color $(9,35,37)$. Thus, a major challenge for common bean breeding is to introgress high levels of $\mathrm{CBB}$ resistance while maintaining or improving the seed yield and quality and other agronomic characteristics.

In this study, we further investigated aspects of this pathosystem. First, we tested the hypothesis that $X$. campestris pv. phaseoli is typically associated with CBB in large-seeded Andean genotypes by characterizing xanthomonads associated with $\mathrm{CBB}$ of dark red kidney (DRK) bean cultivars in central Wisconsin, a region where these genotypes predominate. Second, we assessed whether common bean genotypes with introgressed CBB resistance QTL, especially those with pyramided resistance, are resistant to a diversity of common blight bacteria by determining the response of common bean genotypes having various combinations of CBB resistance QTL to X. campestris pv. phaseoli or $X$. fuscans subsp. fuscans strains representing the different genotypes identified by rep-PCR. This information will help in the selection of germplasm or breeding lines and strains of common blight bacteria for CBB resistance-breeding programs.

\section{MATERIALS AND METHODS}

CBB surveys and isolation of xanthomonad-like bacteria. Surveys for CBB were performed in 2005 and 2006 in a major DRK bean production area in central Wisconsin (Table 1). In all, 26 fields were surveyed over this 2-year period: 11 in 2005 and 15 in 2006. Fields were sampled in mid-August, when plants were in the early to late flowering stage (R1 to R3). Disease incidence was determined by the estimation of the proportion of plants with CBB symptoms in each field: low $(<1 \% \mathrm{CBB})$, moderate ( 1 to $10 \% \mathrm{CBB})$ and high $(>10 \% \mathrm{CBB})$. Trifoliolate leaves with CBBlike symptoms (irregular necrotic lesions with yellow borders and water-soaked spots) were collected, and isolations were performed as previously described (34). Briefly, sections from the margin of healthy and diseased leaf tissue were macerated in

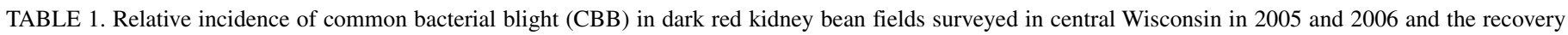
of xanthomonads from leaves with CBB symptoms collected from these fields

\begin{tabular}{|c|c|c|c|c|c|c|}
\hline Year, location & $\mathrm{CBB}_{\text {incidence }}^{\mathrm{a}}$ & No. of xanthomonad-like strains recovered & $\mathrm{P} 1^{\mathrm{b}}$ & $\mathrm{P} 3^{\mathrm{b}}$ & $\mathrm{P} 2^{\mathrm{c}}$ & $\mathrm{P} 4^{\mathrm{d}}$ \\
\hline \multicolumn{7}{|l|}{2005} \\
\hline D. South & $\mathrm{L}$ & 9 & 2 & 3 & 1 & 3 \\
\hline Field no. 5 & $\mathrm{H}$ & 21 & 21 & 0 & 0 & 0 \\
\hline Road 1 & M & 18 & 0 & 15 & 0 & 3 \\
\hline Field no. 1 & M & 12 & 0 & 12 & 0 & 0 \\
\hline Field no. 2 & M & 18 & 15 & 3 & 0 & 0 \\
\hline Field no. 4 & M & 18 & 13 & 0 & 5 & 0 \\
\hline Claveland North & M & 15 & 15 & 0 & 0 & 0 \\
\hline Niece & M & 18 & 0 & 18 & 0 & 0 \\
\hline Field no. 2, Rogers & $\mathrm{L}$ & 21 & 0 & 0 & 0 & 21 \\
\hline Kohler & $\mathrm{L}$ & 18 & 4 & 0 & 0 & 14 \\
\hline Field no. 4 , location 2 & M & 14 & 13 & 0 & 0 & 1 \\
\hline \multicolumn{7}{|l|}{2006} \\
\hline Field no. 3 & $\mathrm{~L}$ & 9 & 3 & 0 & 0 & 6 \\
\hline Field no. 5 & M & 15 & 15 & 0 & 0 & 0 \\
\hline Abbot North & $\mathrm{L}$ & 6 & 6 & 0 & 0 & 0 \\
\hline Arkansas North 1 & $\mathrm{~L}$ & 4 & 0 & 3 & 0 & 1 \\
\hline Arkansas North 2 & $\mathrm{~L}$ & 12 & 0 & 9 & 0 & 3 \\
\hline Claveland North & $\mathrm{L}$ & 6 & 0 & 6 & 0 & 0 \\
\hline Webster South & $\mathrm{L}$ & 6 & 0 & 6 & 0 & 0 \\
\hline D. South & $\mathrm{H}$ & 32 & 0 & 32 & 0 & 0 \\
\hline Field no. 4 & $\mathrm{H}$ & 25 & 25 & 0 & 0 & 0 \\
\hline Flush Shower South & $\mathrm{L}$ & 9 & 6 & 0 & 0 & 3 \\
\hline Knudson & $\mathrm{L}$ & 3 & 3 & 0 & 0 & 0 \\
\hline Quiling 85 & M & 17 & 8 & 9 & 0 & 0 \\
\hline Quiling 126 & M & 10 & 10 & 0 & 0 & 0 \\
\hline Rock Falls East & $\mathrm{L}$ & 6 & 6 & 0 & 0 & 0 \\
\hline Rock Falls North & $\mathrm{L}$ & 6 & 3 & 3 & 0 & 0 \\
\hline Total & $\ldots$ & 348 & 168 & 119 & 6 & 55 \\
\hline
\end{tabular}

${ }^{a} \mathrm{~L}=$ low, $<1 \% \mathrm{CBB}$ incidence; $\mathrm{M}=$ medium, 1 to $10 \% \mathrm{CBB}$ incidence; and $\mathrm{H}=$ high $>10 \% \mathrm{CBB}$ incidence.

${ }^{\mathrm{b}} \mathrm{P} 1=$ phenotype 1 , typical $(\mathrm{P})$ Xanthomonas campestris pv. phaseoli strains, and $\mathrm{P} 3=$ phenotype 3 , intermediate (Px) X. campestris pv. phaseoli strains.

${ }^{c} \mathrm{P} 2=$ phenotype $2, X$. fuscans subsp. fuscans .

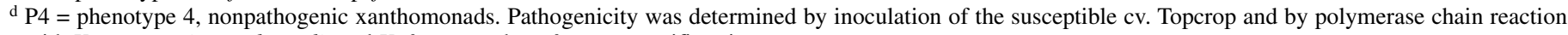
with $X$. campestris pv. phaseoli- and $X$. fuscans subsp. fuscans-specific primers. 
sterile distilled water, and the macerate was diluted and streaked onto plates of MXP, a semiselective media for common blight bacteria (7). Plates were incubated for 3 to 5 days at $28^{\circ} \mathrm{C}$. From each plate, three representative xanthomonads (yellow mucoid colonies surrounded by zones of starch hydrolysis) were subcultured onto 523 media (19). After 3 days of growth at room temperature, the colony characteristics of each isolate, including shape, size, elevation, and extracellular brown pigment and polysaccharide (mucosity) production, were recorded.

Identification of common blight bacteria: pathogenicity in common bean and PCR with $X$. campestris pv. phaseoli- and $X$. fuscans subsp. fuscans-specific primers. Common blight bacteria (X. campestris pv. phaseoli and $X$. fuscans subsp. fuscans strains) were identified based on a general pathogenicity test with the susceptible cv. Topcrop and PCR with primers specific for $X$. campestris pv. phaseoli and X. fuscans subsp. fuscans strains (3). For the pathogenicity test, a suspension of bacterial cells was prepared in sterile distilled water, adjusted to a concentration of 1 $\times 10^{8} \mathrm{CFU} / \mathrm{ml}$, and rub inoculated onto the first trifoliolate leaf dusted with celite (12). The inoculum was kept on ice and used within $3 \mathrm{~h}$. Plants were maintained in a greenhouse (day and night temperatures of 26 and $18^{\circ} \mathrm{C}$, respectively, and relative humidity of 45 to $55 \%$ ). Inoculated leaves were evaluated 14 days postinoculation (dpi). Isolates were rated as pathogenic (presence of water-soaked spots and chlorosis and necrosis around the inoculated area) or nonpathogenic (wound damage but no chlorosis or water-soaking). Controls were sterile distilled water and a known $X$. campestris pv. phaseoli strain (Xcp25). Each isolate was tested twice with two replicates for each experiment.

DNA was extracted from each isolate using a cetyltrimethylammonium bromide DNA extraction protocol (20). PCR with the $X$. campestris pv. phaseoli- and $X$. fuscans subsp. fuscans-specific primer pair (X4c and $\mathrm{X} 4 \mathrm{e}$ ) was performed as previously described (3). This primer pair directs the amplification of an $\approx 700$-bp fragment from total genomic DNA of common blight bacteria. All isolates were tested twice.

Rep-PCR. Fingerprints were generated using rep-PCR primers targeting conserved repetitive sequences as previously described $(24,43,44)$. For each isolate, fingerprints were generated with repetitive extragenic palindromic (REP), enterobacterial repetitive intergenic consensus (ERIC), and BOX 1A primers, as previously described (34). Two reactions were performed for each isolate and each primer pair. The rep-PCR fingerprints were examined visually and compared with fingerprints of the control strains. In addition, fingerprints were also analyzed with GelCompar II V. 4.011 (Applied Maths, Belgium) to produce a dendogram. Results were standardized by comparing the fingerprint of each isolate to the fingerprint of each control.

Sequence analysis of 16S-28S ribosomal RNA spacer region. The 16S-28S ribosomal RNA (rRNA) spacer region was amplified by PCR with the G1/L1 primer pair (16), and sequences were determined as previously described (4). The sequences were compared with those in the GenBank using the BLAST program available at the National Center for Biotechnology Information (NCBI) (http://www.ncbi.nlm.nih.gov/BLAST/), and assembled using the BioEdit program version 7.05 (http://www.mbio.ncsu. edu/BioEdit/bioedit.html). Sequences were aligned using Clustal W (50). Phylogenetic trees were constructed from the aligned sequences using MEGA 4 (21), with a neighbor-joining method and 1,000 bootstrap replicates.

Inoculation of $P$. vulgaris genotypes with strains representative of the genotypic diversity of common blight bacteria. Eight strains were selected to represent the genotypic diversity of $X$. campestris pv. phaseoli and $X$. fuscans subsp. fuscans as revealed by rep-PCR analysis. These included the new $X$. campestris pv. phaseoli Px (strain Px100) and X. fuscans subsp. fuscans FH (strain FH61) genotypes identified in this study. Two typical $X$. campestris pv. phaseoli strains were used: PR1, a strain from Puerto Rico, and Xcp25, a strain isolated from DRK bean in Wisconsin. The two East African X. campestris pv. phaseoli genotypes were represented by strains M11 and T21, respectively (34). The two previously identified $X$. fuscans subsp. fuscans genotypes were represented by PR8F, a New World strain from Puerto Rico, and M12F, an Old World strain from East Africa (34).

In all, 28 common bean genotypes having different combinations of CBB resistance QTL and markers (SAP6, SU91, and BC420) and 2 genotypes lacking known resistance QTL and markers (cvs. Topcrop [Andean] and Sutter Pink [Middle American]) were individually inoculated with each of the eight bacterial strains to assess the host-pathogen interaction. Of the common bean genotypes with resistance QTL, 1 was from the Andean gene pool, 7 were from the Middle-American gene pool, 4 had $P$. coccineus-derived resistance, 5 had $P$. acutifolius-derived resistance, and 11 had pyramided resistance.

Common bean plants were grown in a temperature-controlled greenhouse, as described above. Each plant was grown in a 4-liter pot containing University of California (UC) potting mix. An automated watering system (Argus, White Rock, BC, Canada) was used to apply water daily to the soil for $5 \mathrm{~min}$ each at 7:00 a.m., 10:00 a.m., and 1:00 p.m.. Plants were fertilized every other watering with modified Hoagland's solution. At 17 days post-planting, plants were inoculated with the $X$. campestris pv. phaseoli or X. fuscans subsp. fuscans strains. The three leaflets of three-quarters-expanded first trifoliolate leaves were inoculated with a $1 \times 10^{8} \mathrm{CFU} / \mathrm{ml}$ cell suspension with the razor blade method (41). Disease symptoms on each leaflet were evaluated 21 dpi on a 1-to-9 rating scale (disease severity index [DSI] $1<$ $4=$ resistant, $4<7=$ intermediate, and 7 to $9=$ susceptible) $(22)$. Scores for the three leaflets were averaged to generate a mean DSI for each plant.

Each strain was inoculated onto each host genotype, and plants were arranged in a randomized complete block design (RCBD). Each strain-host combination represented a treatment, and treatments were replicated four times within the RCBD. Two independent experiments were performed in the summer of 2007, with planting dates of 5 and 12 June. Although these two experiments were performed in the same season with similar planting dates, we would expect that results would be consistent over seasons because the experiments were performed under controlled conditions in the greenhouse.

Molecular marker analysis. Samples were taken from primary leaves for DNA extraction and molecular marker analysis. Total genomic DNA was extracted from $\approx 20 \mathrm{mg}$ of primary leaf tissue with the Dellaporta extraction method (8). The marker composition of each plant was determined with a multiplex PCR reaction that allows for the simultaneous detection of the three CBB resistance markers (30). Primers were mixed in equimolar $(2 \mu \mathrm{M})$ concentrations (from a $50-\mu \mathrm{M}$ stock solution) with $20 \mathrm{ng}$ of total genomic DNA, and added to the Qiagen Multiplex Mastermix (Qiagen, Valencia, CA). The amplification conditions included an initial denaturation step at $95^{\circ} \mathrm{C}$ for $15 \mathrm{~min}$; followed by 35 cycles of $94^{\circ} \mathrm{C}$ for $30 \mathrm{~s}$ (denaturation), $58^{\circ} \mathrm{C}$ for $1.5 \mathrm{~min}$ (annealing), and $72^{\circ} \mathrm{C}$ for $1.5 \mathrm{~min}$ (extension); and a final extension step at $72^{\circ} \mathrm{C}$ for $10 \mathrm{~min}$. All PCR reactions were performed in a PTC-100 thermocycler (MJ Research Inc., Waltham, MA). PCR products were analyzed in $1.5 \%$ agarose gels in Tris-acetate-EDTA buffer. Gels were stained with ethidium bromide and DNA was visualized with UV light. The presence or absence of different-sized fragments was determined visually and recorded. All reactions were performed twice. In the few cases where different results were obtained for the two tests, a third test was performed and the consensus result was recorded.

Data analysis. Analysis of variance, mean DSI, standard error, and Fisher's least significant difference values were calculated using the Analyst function in SAS 9.1 (SAS Institute Inc., Cary, 
NC). The CBB DSI values from the host-pathogen interaction analyses met all statistical assumptions and, thus, the data from the two independent experiments were combined. GelCompar II was used to analyze the rep-PCR fingerprints and produce an unweighted pair-group method with arithmetic means (UPGMA) dendogram using the composite data from all three rep-PCR primer sets. The similarity coefficient was calculated using the Pearson correlation coefficient.

\section{RESULTS}

CBB surveys and isolation of xanthomonad-like bacteria. Surveys of DRK bean fields in central Wisconsin in 2005 and 2006 revealed CBB symptoms (irregular necrotic lesions with yellow borders and water-soaked spots) in all fields of this major production area $(\approx 1,200$ ha). In most fields, CBB incidence was low $(<1 \%)$ or moderate (1 to $10 \%$ ) (Table 1). Representative symptomatic leaves were collected from each field. In some fields with low disease incidence, this was complicated by "pseudoCBB" symptoms, which are irregular necrotic lesions with yellow borders (but lacking water-soaking) due to an abiotic disease induced by heat and water stress. Xanthomonad-like bacteria (yellow mucoid colonies surrounded by zones of starch hydrolysis on MXP medium) were isolated from all symptomatic leaves collected and, in total, 348 isolates (individual colonies) representing all the surveyed fields were selected for further characterization (Table 1).

Phenotypic properties of xanthomonad-like bacteria. Each of the 348 xanthomonad-like isolates was subcultured onto 523 medium. Based on colony morphology and brown pigment production, four phenotypes were identified (Table 2). Phenotype 1 colonies were large, yellow, mucoid, convex, and did not produce brown pigment (Fig. 1A). This was the most common phenotype (48\% of the isolates), and isolates were recovered from 17 of the 26 fields. Phenotype 2 colonies were yellow but less mucoid and flatter compared with phenotype 1 colonies. These colonies produced a large quantity of brown pigment (Fig. 1B). Only six phenotype 2 isolates were isolated, and these came from two fields surveyed in 2005. Phenotype 3 colonies were yellow, less mucoid, and convex to flat, more similar to phenotype 2 than

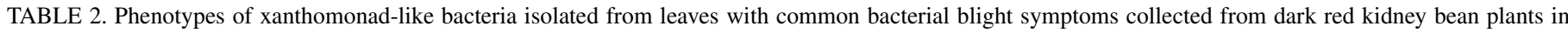
central Wisconsin in 2005 and 2006

\begin{tabular}{|c|c|c|c|c|}
\hline Phenotype & Colony morphology & Brown pigment production & No. of strains $(\%)^{\mathrm{a}}$ & No. of fields \\
\hline $\mathrm{Xcp} 25^{\mathrm{b}}$ & Yellow, mucoid, convex & None & $\mathrm{NA}^{\mathrm{c}}$ & NA \\
\hline PR8Fd & Yellow, less mucoid, convex-flat & High & NA & NA \\
\hline 1 & Yellow, mucoid, convex & None & $168(48)$ & 17 \\
\hline 2 & Yellow, less mucoid, convex-flat & High & $6(2)$ & 2 \\
\hline 3 & Yellow, less mucoid, convex-flat & Low & $119(34)$ & 12 \\
\hline 4 & Light to dark yellow, mucoid to nonmucoid, convex-flat & None & $55(16)$ & 9 \\
\hline
\end{tabular}

${ }^{a}$ Indicates the number of strains of each phenotype that were recovered from a total of 348 strains. Numbers in parentheses are percentages of the total.

b Known strain of Xanthomonas campestris pv. phaseoli.

c NA = not applicable.

${ }^{\mathrm{d}}$ Known strain of $X$. fuscans subsp. fuscans.

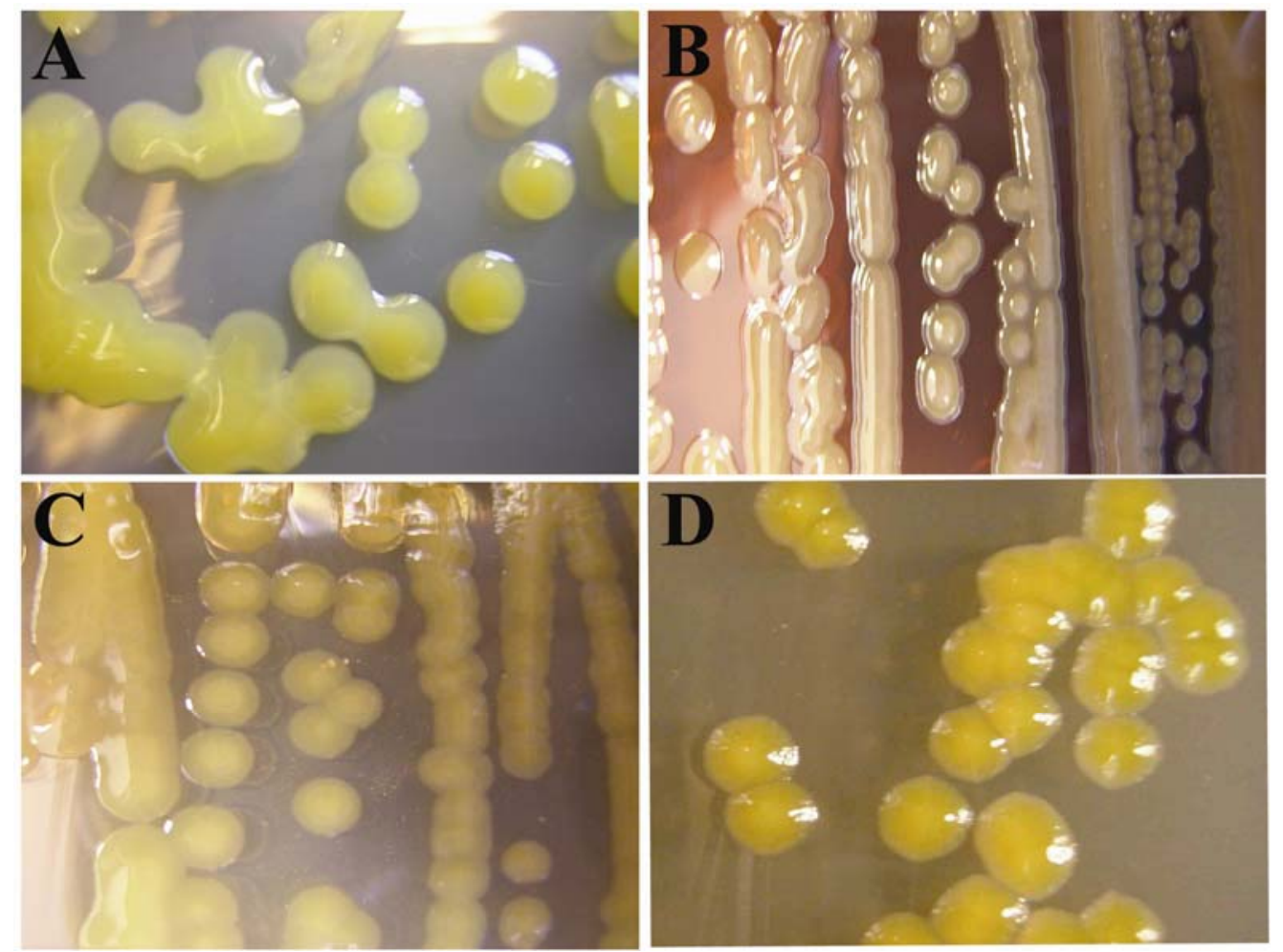

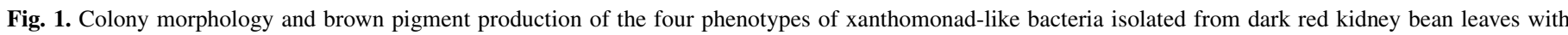

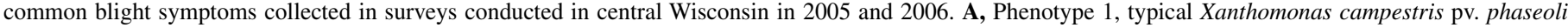

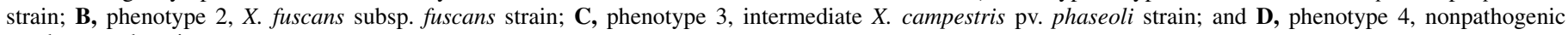
xanthomonad strain. 
phenotype 1 colonies (Fig. 1C). Phenotype 3 colonies also produced brown pigment but substantially less than phenotype 2 colonies (compare Fig. 1B and C; Table 2). This phenotype was also commonly isolated (34\% of the isolates), and isolates were recovered from 12 of the 26 fields. Phenotype 4 isolates were more heterogeneous, with colonies that were light to dark yellow, mucoid to nonmucoid, and convex to flat; these isolates did not produce brown pigment. This phenotype comprised $16 \%$ of the isolates and was recovered from nine fields, most of which had low CBB incidence and pseudo-CBB symptoms.

Identification of $X$. campestris pv. phaseoli or $X$. fuscans subsp. fuscans strains: pathogenicity on common bean and detection by PCR with $X$. campestris pv. phaseoli- and $X$. fuscans subsp. fuscans-specific primers. All 348 isolates were tested for pathogenicity on the susceptible cv. Topcrop. Phenotype 1,2 , and 3 isolates were pathogenic, producing necrotic lesions with yellow borders and water-soaked spots along the inoculated area, whereas phenotype 4 isolates were nonpathogenic, with only mechanical wound damage in the inoculated area. Thus, the phenotype 4 isolates likely represent nonpathogenic xanthomonads, similar to those previously described by Gilbertson et al. (12). Based upon comparison with phenotypes of known X. campestris pv. phaseoli and $X$. fuscans subsp. fuscans strains (Table 2 ), phenotype 1 isolates were similar to X. campestris pv. phaseoli (i.e., yellow mucoid colonies with no brown pigment production), whereas phenotype 2 isolates were similar to $X$. fuscans subsp. fuscans (i.e., yellow, less mucoid colonies with copious brown pigment production). Phenotype 3 colonies were yellow and moderately mucoid but produced brown pigment like $X$. fuscans subsp. fuscans; thus, these were referred to as intermediate strains.

Phenotype 1, 2, and 3 isolates were positive in the PCR test with the X. campestris pv. phaseoli- and X. fuscans subsp. fuscansspecific primers (i.e., the expected-size 700-bp fragment was amplified), whereas phenotype 4 isolates were negative (no fragment was amplified). These results were consistent with results of the pathogenicity tests and, together, indicate that phenotype 1,2 , and 3 isolates are common blight bacteria. Finally, it is interesting to note that, although these phenotypes were occasionally isolated from the same field, it was more common that a single phenotype was predominant in a given field (Table 1).

Rep-PCR analysis. In preliminary experiments performed with the REP primers, known $X$. campestris pv. phaseoli strains were distinguished from $X$. fuscans subsp. fuscans strains, and the three previously reported $X$. campestris pv. phaseoli genotypes were also differentiated (Fig. 2A to C). The two X. fuscans subsp. fuscans genotypes were differentiated with the ERIC but not the REP primers (compare Fig. 2A and B). The BOX primers differentiated $X$. campestris pv. phaseoli and $X$. fuscans subsp. fuscans strains but not the $X$. campestris pv. phaseoli or $X$. fuscans subsp. fuscans genotypes (Fig. 2C). These results were in agreement with previous reports $(23,34)$.

Analysis of the 293 isolates of common blight bacteria isolated from DRK bean fields in Wisconsin with rep-PCR revealed three distinct types of fingerprints. All 168 phenotype 1 isolates, including representative strain Xcp25, had identical rep-PCR fingerprints (Fig. 3A), and these fingerprints were identical to those of the typical $X$. campestris pv. phaseoli strain PR1 (Fig. 2A to C, compare lanes 5 and 6 ). Thus, these results support the notion that phenotype 1 isolates are typical $X$. campestris pv. phaseoli strains.

All six phenotype 2 isolates, including representative strain FH61 had identical rep-PCR fingerprints (Fig. 3B), which were similar to those of the known $X$. fuscans subsp. fuscans strains (Fig. 2A to C, compare lanes 8 to 10). Taken together with the production of brown pigment, these results indicated that phenotype 2 isolates are X. fuscans subsp. fuscans. Furthermore, the Wisconsin $X$. fuscans subsp. fuscans strains were differentiated from the two known $X$. fuscans subsp. fuscans genotypes based on fingerprints generated with the ERIC primers. Here, the

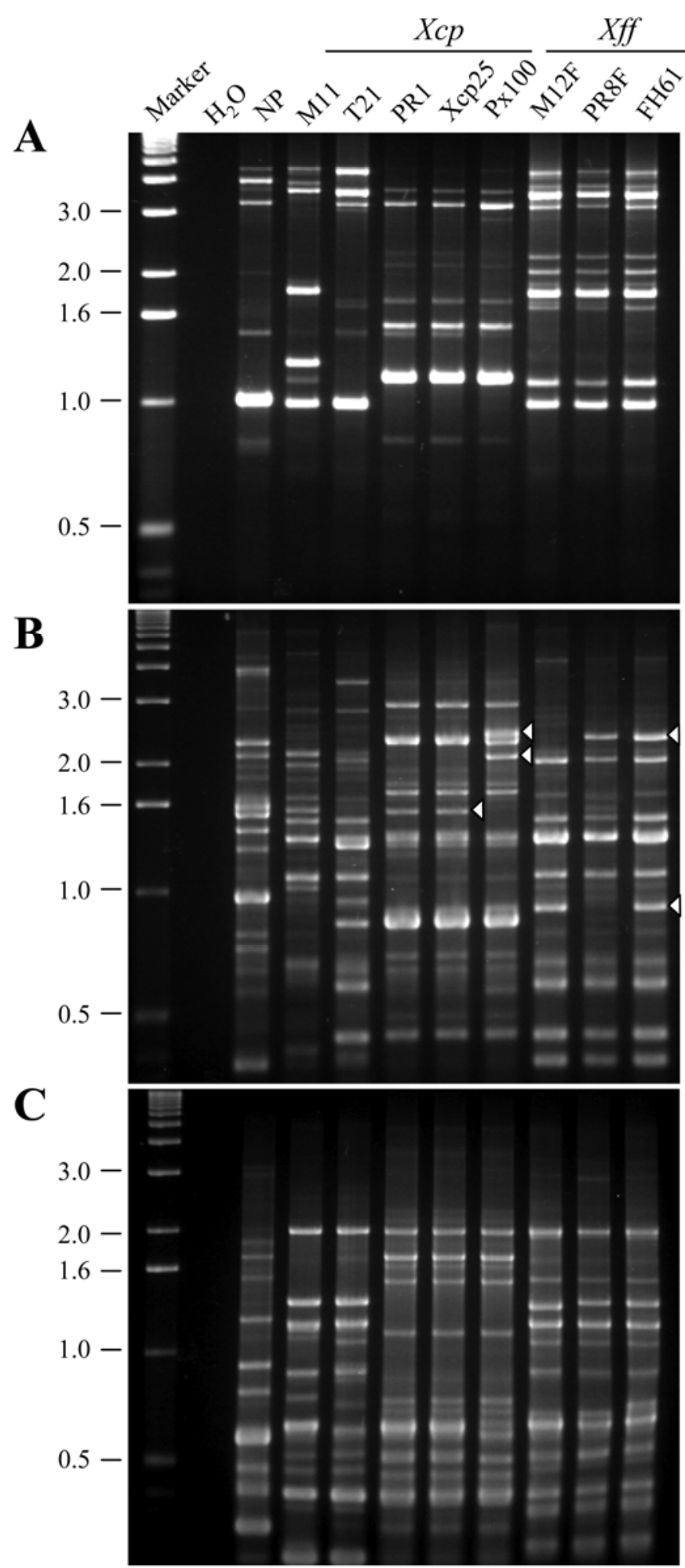

Fig. 2. Agarose gel showing DNA fingerprint patterns generated from total genomic DNA of Xanthomonas campestris pv. phaseoli $(X c p)$ and X. fuscans subsp. fuscans (Xff) strains used in the host-pathogen study. A, Repetitive extragenic palindromic primers; $\mathbf{B}$, enterobacterial repetitive intergenic consensus primers; and $\mathbf{C}, \mathrm{BOX}$ primers. Lane 1, negative control (sterile $\mathrm{H}_{2} \mathrm{O}$ ); lane 2, nonpathogenic xanthomonad (NP); lane 3, X. campestris pv. phaseoli strain from East Africa (M11); lane 4, X. campestris pv. phaseoli strain from East Africa (T21); lane 5, typical X. campestris pv. phaseoli strain from Puerto Rico (PR1); lane 6, typical X. campestris pv. phaseoli strain from Wisconsin (Xcp25); lane 7, intermediate $X$. campestris pv. phaseoli strain from Wisconsin (Px100); lane 8, X. fuscans subsp. fuscans strain from East Africa (M12F); lane 9, X. fuscans subsp. fuscans strain from Puerto Rico (PR8F); and lane 10, X. fuscans subsp. fuscans strain from Wisconsin (FH61). Size markers are indicated (kb) (1-kb ladder, Invitrogen). 
fingerprints of the Wisconsin $X$. fuscans subsp. fuscans strains had $\approx 2.4$ - and $\approx 0.9$-kb fragments, whereas those of the other $X$. fuscans subsp. fuscans genotypes had only one of these fragments (Fig. 2B, compare lanes 8 to 10). This new X. fuscans subsp. fuscans genotype is referred to as $\mathrm{FH}$.

All 119 phenotype 3 (intermediate) isolates, including representative strain Px100, had identical rep-PCR fingerprints (Fig. $3 C$ ), and these were nearly identical to those of the typical $X$. campestris pv. phaseoli strains (Fig. $2 \mathrm{~A}$ to $\mathrm{C}$, compare lanes 5 to 7). However, the phenotype 3 isolates were differentiated from the typical X. campestris pv. phaseoli strains (Xcp25 and PR1) based on fingerprints generated with the ERIC primers. Here, the typical $X$. campestris $\mathrm{pv}$. phaseoli strains had an $\approx 1.5-\mathrm{kb}$ fragment that the phenotype 3 isolates lacked, whereas the phenotype 3 isolates had $\approx 2.1$ - and $\approx 2.4-\mathrm{kb}$ fragments that the typical $X$. campestris $\mathrm{pv}$. phaseoli strains lacked (Fig. 2B, compare lanes 5 to 7). Thus, although the phenotype 3 isolates had an intermediate phenotype, they were nearly identical, genotypically, to typical $X$. campestris pv. phaseoli strains. This new X. campestris pv. phaseoli phenotype and genotype is referred to as Px.

Finally, the 55 nonpathogenic phenotype 4 isolates, including representative strain NP, had a diversity of rep-PCR fingerprints (Fig. 3D), all of which were distinct from those of $X$. campestris pv. phaseoli and X. fuscans subsp. fuscans strains (Fig. 2A to C). These results established that these isolates compose a genetically diverse group of nonpathogenic xanthomonads.

An UPGMA cluster analysis was performed with data generated from the three rep-PCR analyses of the eight strains repre- senting the genotypic diversity of $X$. campestris pv. phaseoli and $X$. fuscans subsp. fuscans and one nonpathogenic xanthomonad strain (Table 3; Fig. 4). The three X. campestris pv. phaseoli strains with New World origins (PR1, Xcp25, and Px100) clustered together with $\geq 94 \%$ similarity, with the new $X$. campestris pv. phaseoli $\mathrm{Px}$ phenotype and genotype most divergent. The three $X$. fuscans subsp. fuscans strains also clustered together, with $\approx 90 \%$ similarity. The two $X$. fuscans subsp. fuscans strains with New World origins (PR8F and new genotype FH61) were more similar than the strain from the Old World (M12F). The two East African X. campestris pv. phaseoli strains (M11 and T21) were distinct from the other $X$. campestris pv. phaseoli strains and from the $X$. fuscans subsp. fuscans strains. Interestingly, on the basis of this analysis, these East African $X$. campestris pv. phaseoli genotypes were more similar to the $X$. fuscans subsp. fuscans strains than to the other $X$. campestris pv. phaseoli strains (Fig. 4). The nonpathogenic xanthomonad strain (NP) was genetically distinct from all $X$. campestris pv. phaseoli and $X$. fuscans subsp. fuscans strains, with $<45 \%$ similarity.

16S-28S rRNA spacer region sequence analysis. The $16 \mathrm{~S}$ 28S rRNA spacer region sequences (493 nucleotides [nt]) of the eight common blight bacteria strains had a high level (>95\%) of sequence identity. The sequences of the three $X$. campestris pv. phaseoli strains with New World origins (PR1, Px100, and Xcp25) were identical, as were those of the three $X$. fuscans subsp. fuscans strains (M12F, PR8F, and FH61). These X. campestris pv. phaseoli and $X$. fuscans subsp. fuscans sequences were $98 \%$ identical, with most of the 9 nt differences located in one

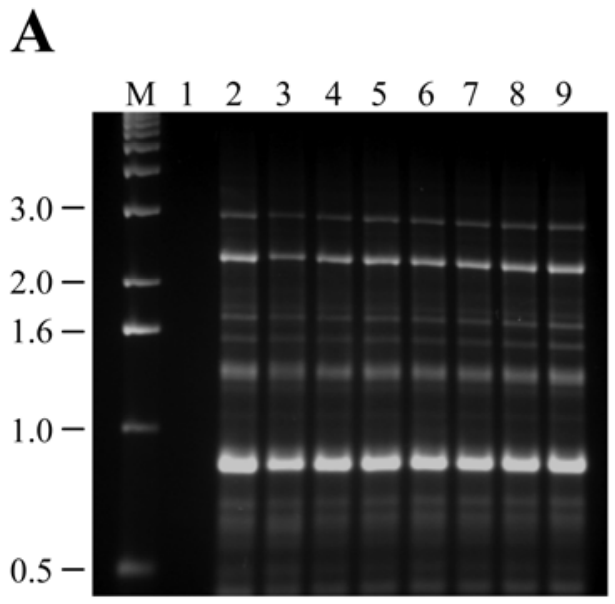

B

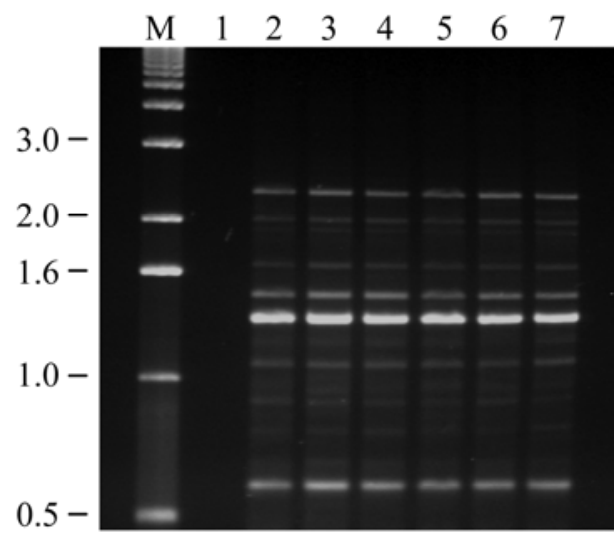

C

D
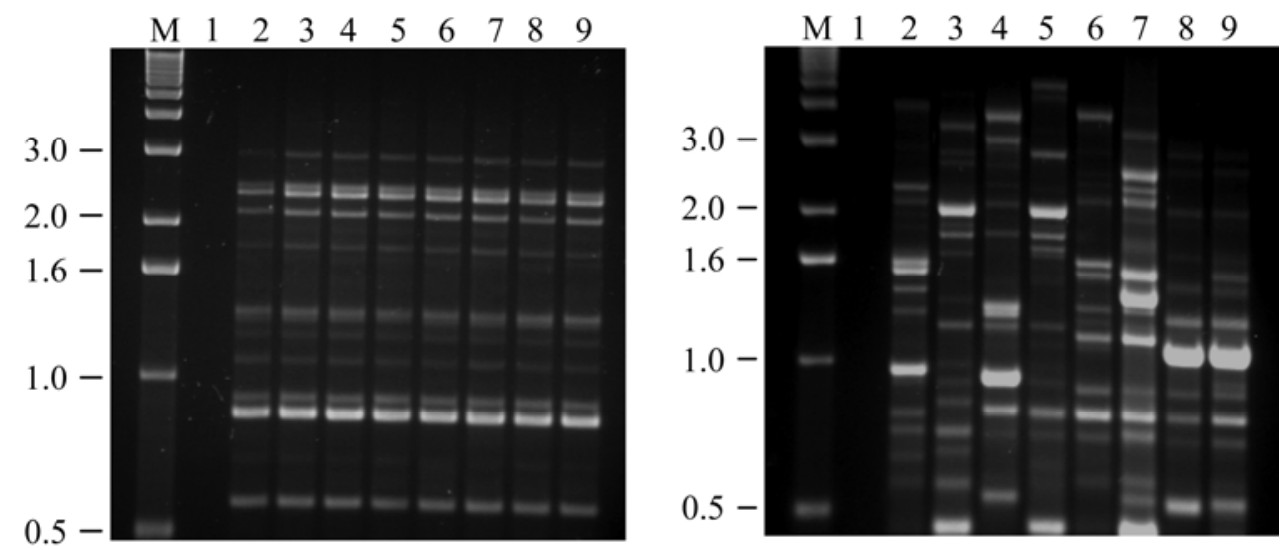

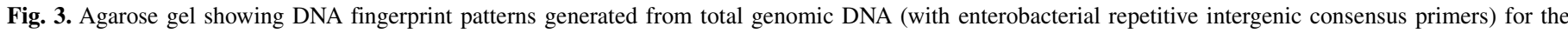

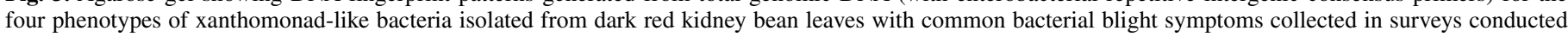

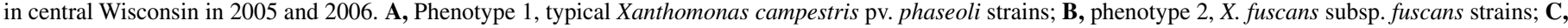

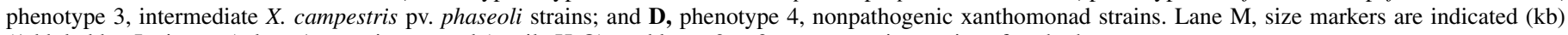
(1-kb ladder, Invitrogen); lane 1, negative control (sterile $\mathrm{H}_{2} \mathrm{O}$ ); and lanes 2 to 9, representative strains of each phenotype. 
region. The sequences of the East African $X$. campestris pv. phaseoli genotypes (M11 and T21) were identical to each other and nearly identical to those of $X$. fuscans subsp. fuscans strains, differing in only a single nucleotide. Consistent with these results, the $X$. campestris pv. phaseoli and X. fuscans subsp. fuscans spacer region sequences in the GenBank, which are from African strains, were nearly identical to those of the East African X. campestris pv. phaseoli genotypes and X. fuscans subsp. fuscans strains. These results suggest that the East African $X$. campestris pv. phaseoli genotypes may be more closely related to $X$. fuscans subsp. fuscans strains than to typical $X$. campestris pv. phaseoli strains, which is in agreement with results of the rep-PCR analyses (Fig. 4).

To gain further insight into the significance of the sequence divergence in the spacer region sequences of common blight bacteria, comparisons were performed with sequences of other xanthomonad pathovars or species. The $X$. campestris pv. phaseoli and X. fuscans subsp. fuscans sequences were $99 \%$ identical with that of $X$. axonopodis pv. dieffenbachiae and $98 \%$ identical with those of $X$. axonopodis pv. citri, $X$. axonopodis pv. malvacearm, and $X$. campestris pv. vesicatoria. Slightly lower identities were obtained in comparisons with sequences of $X$. campestris pv. vitians (97\%), X. campestris pv. carotae $(96 \%)$, and $X$. campestris pv. campestris $(95 \%)$. These results revealed that the 16S-28S spacer region sequence is conserved among these xanthomonads, and that the level of divergence in the sequences of typical $X$. campestris pv. phaseoli and $X$. fuscans subsp. fuscans strains, and possibly in the East African $X$. campestris pv. phaseoli strains, was consistent with these genotypes representing different species. Our results also revealed a region of sequence diversity in the spacer sequence, located between nucleotides 465 and 477 .

Host-pathogen interaction. All of the selected common blight bacteria strains (Table 4), except $X$. fuscans subsp. fuscans PR8F, were significantly more virulent on the susceptible Andean cv. Topcrop than on the Middle-American cv. Sutter Pink (note that neither cultivar possesses known $\mathrm{CBB}$ resistance genes). The typical X. campestris pv. phaseoli strain from Wisconsin (Xcp25) was most virulent on cv. Topcrop; whereas the new $X$. fuscans subsp. fuscans genotype from Wisconsin (FH61) was most virulent on cv. Sutter Pink.

When inoculated onto the series of common bean genotypes with CBB resistance QTL, the genotypes of common blight bacteria showed a range of virulence variability. The typical $X$. campestris pv. phaseoli strain from Wisconsin (Xcp25) was most virulent on most genotypes, followed by Px100 (the new brownpigmented $X$. campestris pv. phaseoli phenotype and genotype) and PR1, respectively. Strains Xcp25 and Px100 showed similar virulence on most genotypes, whereas strain PR1 (typical $X$. campestris pv. phaseoli from Puerto Rico) was significantly less virulent on a number of genotypes, particularly those with the SAP6 marker (e.g., Chase, Montcalm, TARS VCI-4B, ICB 3, ICB

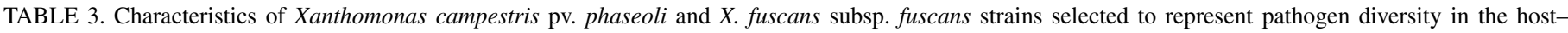
pathogen interaction study

\begin{tabular}{|c|c|c|c|c|c|c|c|}
\hline Strain & Species & Geographical origin & Gene pool source ${ }^{a}$ & Phenotype $^{b}$ & Genotype $^{c}$ & Pathogenicity $^{\mathrm{d}}$ & PCR ID \\
\hline PR1 & X. campestris pv. phaseoli & Puerto Rico & Andean & 1 & $\mathrm{P}$ & + & + \\
\hline Xcp25 & $X$. campestris pv. phaseoli & Wisconsin & Andean & 1 & $\mathrm{P}$ & + & + \\
\hline Px100 & X. campestris pv. phaseoli & Wisconsin & Andean & 3 & Px & + & + \\
\hline M11 & X. campestris pv. phaseoli & Malawi & Andean & 1 & EA1 & + & + \\
\hline $\mathrm{T} 21$ & X. campestris pv. phaseoli & Tanzania & Andean & 1 & EA2 & + & + \\
\hline PR8F & $X$. fuscans subsp. fuscans & Puerto Rico & Middle American & 2 & NWF & + & + \\
\hline $\mathrm{M} 12 \mathrm{~F}$ & X. fuscans subsp. fuscans & Malawi & Andean & 2 & EAF & + & + \\
\hline FH61 & X. fuscans subsp. fuscans & Wisconsin & Andean & 2 & $\mathrm{FH}$ & + & + \\
\hline
\end{tabular}

a Indicates the gene pool of the common bean cultivar from which the strain was isolated.

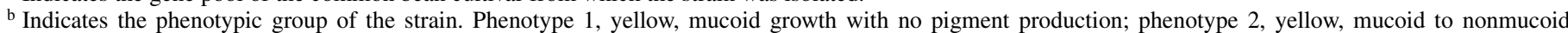
growth with copious brown pigment production; and phenotype 3, yellow, mucoid to nonmucoid growth with a low level of brown pigment production.

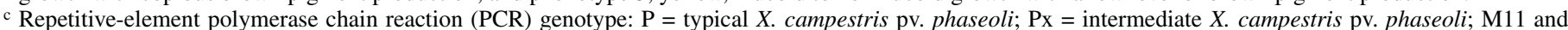
T21 represent East African (EA) X. campestris pv. phaseoli genotypes 1 and 2, respectively; NWF $=$ New World $X$. fuscans subsp. fuscans; EAF $=$ East African $X$. fuscans subsp. fuscans; and $\mathrm{FH}=$ the new Wisconsin $X$. fuscans subsp. fuscans genotype.

d Symbol (+) indicates strain was pathogenic on the susceptible cv. Topcrop.

e Symbol (+) indicates strain was positive in the PCR with the X. campestris pv. phaseoli- and X. fuscans subsp. fuscans-specific primers.

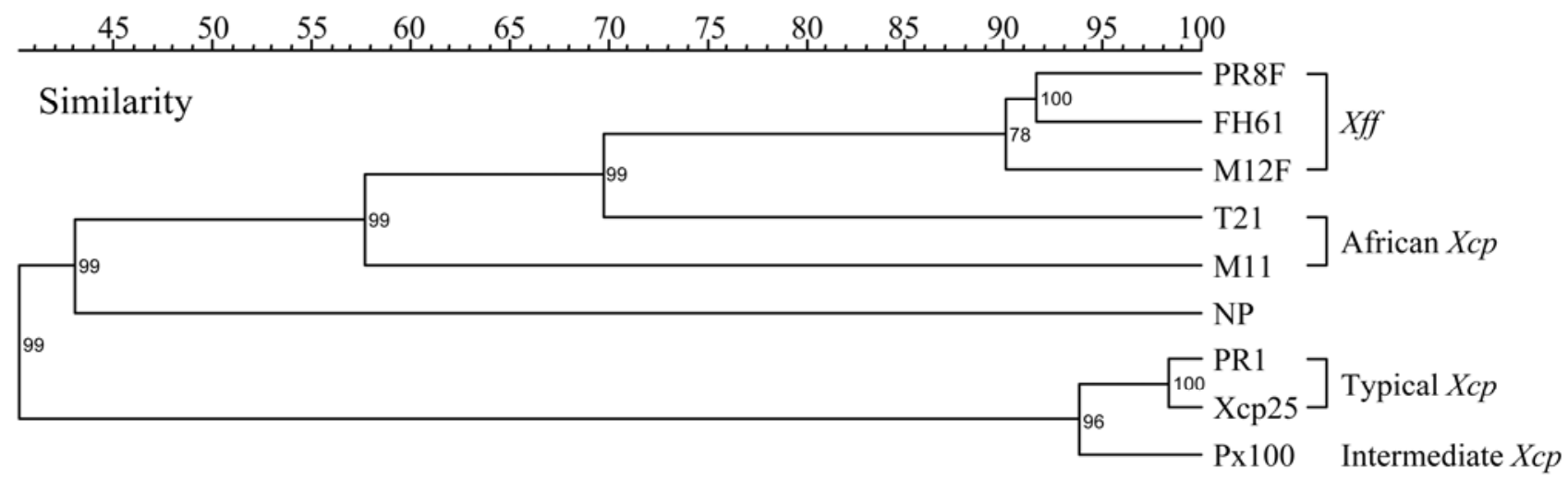

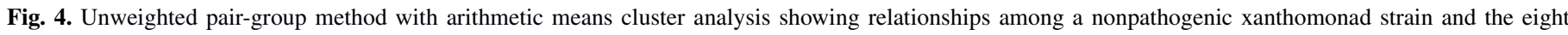

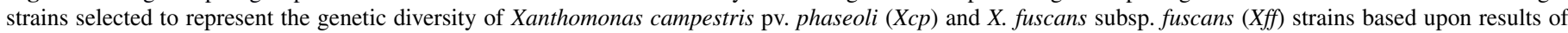

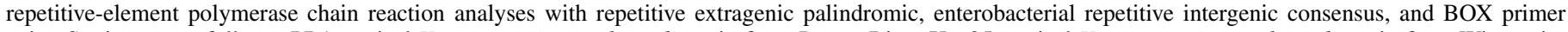

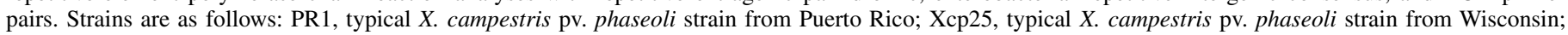

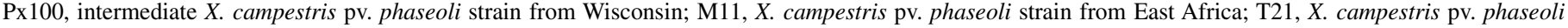

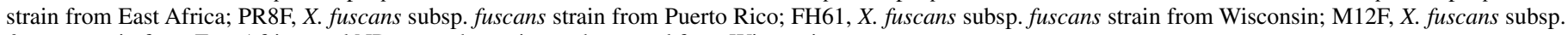
fuscans strain from East Africa; and NP, nonpathogenic xanthomonad from Wisconsin. 
11, ICB 67, VAX 1, VAX 2, G 17341, and G 17344) or with the SAP6 and SU91 markers (e.g., USPT-CBB-5) (Table 4). However, the most striking variability was observed for the East African strains (M11 and T21), which were significantly less virulent than the other $X$. campestris pv. phaseoli strains and the $X$. fuscans subsp. fuscans strains on most host genotypes (Table 4). An exception was on genotype OAC Rex, where the East African $X$. campestris pv. phaseoli strain T21 was the most virulent strain. The East African strains were similar in virulence on most genotypes but $\mathrm{T} 21$ was significantly more virulent on a number of genotypes, including ICB 11, 53, and 67 (with $P$. coccineus-derived resistance) and OAC Rex and OAC 88-1 (with $P$. acutifolius-derived resistance). The East African $X$. campestris pv. phaseoli strains and the typical $X$. campestris pv. phaseoli strain PR1 were also significantly less virulent than other $X$. campestris pv. phaseoli strains (Xcp25 and Px) on most of the bean genotypes with the SAP6 marker (Table 4).

In contrast to the virulence variability observed for $X$. campestris pv. phaseoli strains, $X$. fuscans subsp. fuscans strains were similar in virulence, with only minor differences observed on a few genotypes (e.g., ICB 67, VAX 1, and G 17341). Overall, the $X$. fuscans subsp. fuscans FH61 strain was most virulent followed by PR8F and M12F, respectively (Table 4); and X. fuscans subsp. fuscans strains were slightly less virulent compared with the most virulent $X$. campestris pv. phaseoli strain (Table 4).
Eight host genotypes were resistant to all eight pathogen genotypes, and most of these had pyramided resistance associated with the SU91 marker and one or both of the other markers (SAP6 and BC420) (Table 4). The highest levels of resistance were observed in the VAX breeding lines (especially lines VAX 3, VAX 4, VAX 5, and VAX 6), which have pyramided resistance associated with the SAP6 and SU91 markers. The one genotype with only the SU91 marker, OAC Rex, also had a high level of resistance, though not as high as the genotypes with pyramided resistance. Other host genotypes with pyramided resistance that also showed high levels of resistance included HR 45, Wilkinson 2, XAN 159, and XAN 309. These genotypes had SAP6 and SU91 (XAN 309), SU91 and BC420 (XAN 159 and Wilkinson 2), or all three markers (HR 45). Thus, the SU91 marker was consistently associated with high levels of resistance. Most of these highly resistant host genotypes were small seeded, although Wilkinson 2 and XAN 159 have a medium seed size.

In addition to the highly CBB-resistant genotypes, several other genotypes showed good levels of CBB resistance (Table 4). These included ICB 3, VAX 1, VAX 2, OAC Rex, OAC 88-1, and USPTCBB-5. These host genotypes had various combinations of markers: ICB 3, VAX 1, and VAX 2 had SAP6; OAC Rex had SU91; and OAC 88-1 and USPT-CBB-5 had SAP6 and SU91. A number of other genotypes showed resistant or low intermediate responses (DSI values $<5.0$ ) to some pathogen genotypes; these

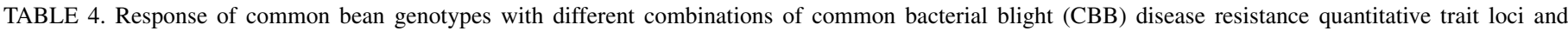

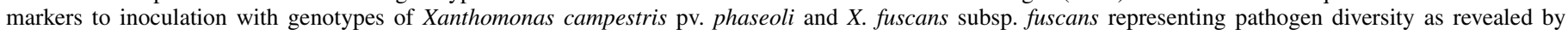
repetitive-element polymerase chain reaction analyses ${ }^{\mathrm{a}}$

\begin{tabular}{|c|c|c|c|c|c|c|c|c|c|c|c|c|}
\hline \multirow[b]{3}{*}{ Genotype } & \multirow[b]{3}{*}{ Source ${ }^{b}$} & \multirow[b]{3}{*}{ Marker } & \multicolumn{8}{|c|}{ Mean disease rating ${ }^{c}$} & \multirow[b]{3}{*}{ Mean } & \multirow[b]{3}{*}{$\mathrm{LSD}^{\mathrm{e}}$} \\
\hline & & & \multicolumn{5}{|c|}{ X. campestris pv. phaseoli ${ }^{\mathrm{d}}$} & \multicolumn{3}{|c|}{ X. fuscans subsp. fuscans } & & \\
\hline & & & PR1 & Xcp25 & Px 100 & M11 & $\mathrm{T} 21$ & PR8F & $\mathrm{M} 12 \mathrm{~F}$ & FH61 & & \\
\hline Topcrop & $\mathrm{A}(\mathrm{S})$ & None & $8.2 \mathrm{~S}$ & $8.7 \mathrm{~S}$ & $8.0 \mathrm{~S}$ & $4.5 \mathrm{I}$ & $5.5 \mathrm{I}$ & $6.9 \mathrm{I}$ & $7.3 \mathrm{~S}$ & $7.5 \mathrm{~S}$ & $7.1 \mathrm{~S}$ & 0.50 \\
\hline Sutter Pink & $M(S)$ & None & $6.8 \mathrm{I}$ & $6.5 \mathrm{I}$ & $6.8 \mathrm{I}$ & $4.0 \mathrm{I}$ & $4.7 \mathrm{I}$ & $6.9 \mathrm{I}$ & $6.0 \mathrm{I}$ & $7.0 \mathrm{~S}$ & $6.1 \mathrm{I}$ & 0.40 \\
\hline G 1320 & $\mathrm{M}$ & None & $5.5 \mathrm{I}$ & $5.9 \mathrm{I}$ & $5.6 \mathrm{I}$ & $2.5 \mathrm{R}$ & $3.4 \mathrm{R}$ & $5.4 \mathrm{I}$ & $5.5 \mathrm{I}$ & $6.0 \mathrm{I}$ & $5.0 \mathrm{I}$ & 0.30 \\
\hline XAN 91 & M & None & $5.6 \mathrm{I}$ & $5.8 \mathrm{I}$ & $5.1 \mathrm{I}$ & $2.0 \mathrm{R}$ & $2.9 \mathrm{R}$ & $5.5 \mathrm{I}$ & $5.1 \mathrm{I}$ & $5.0 \mathrm{I}$ & $4.6 \mathrm{I}$ & 0.70 \\
\hline ICB 53 & $P c$ & None & $4.5 \mathrm{I}$ & $6.8 \mathrm{I}$ & $6.3 \mathrm{I}$ & $2.7 \mathrm{R}$ & $\underline{4.5 \mathrm{I}}$ & $5.6 \mathrm{I}$ & $5.6 \mathrm{I}$ & $6.0 \mathrm{I}$ & $5.2 \mathrm{I}$ & 0.32 \\
\hline Chase & M & SAP6 & $3.7 \mathrm{R}$ & $7.5 \mathrm{~S}$ & $6.7 \mathrm{I}$ & $\overline{4.3 I}$ & $\overline{4.8 I}$ & $6.7 \mathrm{I}$ & $6.8 \mathrm{I}$ & $6.8 \mathrm{I}$ & $5.9 \mathrm{I}$ & 0.29 \\
\hline Colima 9 & M & SAP6 & $5.3 \mathrm{I}$ & $5.7 \mathrm{I}$ & $5.3 \mathrm{I}$ & $2.3 \mathrm{R}$ & $2.7 \mathrm{R}$ & $5.5 \mathrm{I}$ & $4.7 \mathrm{I}$ & $5.9 \mathrm{I}$ & $4.7 \mathrm{I}$ & 0.33 \\
\hline Montana 5 & M & SAP6 & $4.4 \mathrm{I}$ & $7.2 \mathrm{~S}$ & $6.3 \mathrm{I}$ & $2.4 \mathrm{R}$ & $3.5 \mathrm{R}$ & $6.6 \mathrm{I}$ & $6.0 \mathrm{I}$ & $6.7 \mathrm{I}$ & $5.4 \mathrm{I}$ & 0.30 \\
\hline Montcalm & A & SAP6 & $5.2 \mathrm{I}$ & $8.2 \mathrm{~S}$ & $7.4 \mathrm{~S}$ & $4.9 \mathrm{I}$ & $4.0 \mathrm{I}$ & $6.8 \mathrm{I}$ & $6.1 \mathrm{I}$ & $6.8 \mathrm{I}$ & $6.2 \mathrm{I}$ & 0.40 \\
\hline TARS VCI-4B & M & SAP6 & $3.2 \mathrm{R}$ & $6.5 \mathrm{I}$ & $5.6 \mathrm{I}$ & $2.3 \mathrm{R}$ & $3.1 \mathrm{R}$ & $5.5 \mathrm{I}$ & $6.1 \mathrm{I}$ & $6.1 \mathrm{I}$ & $4.8 \mathrm{I}$ & 0.45 \\
\hline Tamaulipa 9-B & M & SAP6 & $6.0 \mathrm{I}$ & $6.8 \mathrm{I}$ & $6.0 \mathrm{I}$ & $2.5 \mathrm{R}$ & $3.1 \mathrm{R}$ & $6.0 \mathrm{I}$ & $5.3 \mathrm{I}$ & $6.1 \mathrm{I}$ & $5.2 \mathrm{I}$ & 0.25 \\
\hline ICB 3 & $P c$ & SAP6 & $3.0 \mathrm{R}$ & $5.3 \mathrm{I}$ & $4.4 \mathrm{I}$ & $2.0 \mathrm{R}$ & $2.0 \mathrm{R}$ & $5.1 \mathrm{I}$ & $4.1 \mathrm{I}$ & $5.6 \mathrm{I}$ & $3.9 \mathrm{R}$ & 0.43 \\
\hline ICB 11 & $P c$ & SAP6 & $4.9 \mathrm{I}$ & $7.6 \mathrm{~S}$ & $7.0 \mathrm{~S}$ & $\underline{3.0 \mathrm{R}}$ & $\underline{4.3 I}$ & $6.1 \mathrm{I}$ & $5.4 \mathrm{I}$ & $6.3 \mathrm{I}$ & $5.6 \mathrm{I}$ & 0.35 \\
\hline ICB 67 & $P c$ & SAP6 & $3.5 \mathrm{R}$ & $8.0 \mathrm{~S}$ & $7.2 \mathrm{~S}$ & $\overline{2.5 \mathrm{R}}$ & $\overline{4.3 \mathrm{I}}$ & $6.5 \mathrm{I}$ & $6.2 \mathrm{I}$ & $7.1 \mathrm{~S}$ & $5.6 \mathrm{I}$ & 0.30 \\
\hline VAX 1 & $\mathrm{~Pa}$ & SAP6 & $2.2 \mathrm{R}$ & $4.4 \mathrm{I}$ & $4.1 \mathrm{I}$ & $\overline{2.1 \mathrm{R}}$ & $\overline{2.4 \mathrm{R}}$ & $4.0 \mathrm{I}$ & $3.9 \mathrm{R}$ & $4.5 \mathrm{I}$ & $3.5 \mathrm{R}$ & 0.27 \\
\hline VAX 2 & $\mathrm{~Pa}$ & SAP6 & $2.3 \mathrm{R}$ & $5.1 \mathrm{I}$ & $4.5 \mathrm{I}$ & $2.0 \mathrm{R}$ & $2.0 \mathrm{R}$ & $4.9 \mathrm{I}$ & $4.4 \mathrm{I}$ & $4.9 \mathrm{I}$ & $3.8 \mathrm{R}$ & 0.30 \\
\hline G 17341 & Pyr & SAP6 & $2.1 \mathrm{R}$ & $4.3 \mathrm{I}$ & $3.3 \mathrm{I}$ & $2.0 \mathrm{R}$ & $2.2 \mathrm{R}$ & $3.3 \mathrm{R}$ & $3.0 \mathrm{R}$ & $4.0 \mathrm{I}$ & $3.0 \mathrm{R}$ & 0.38 \\
\hline G 17344 & Pyr & SAP6 & $2.7 \mathrm{R}$ & $4.1 \mathrm{I}$ & $4.1 \mathrm{I}$ & $2.8 \mathrm{R}$ & $2.7 \mathrm{R}$ & $3.6 \mathrm{R}$ & $3.4 \mathrm{R}$ & $4.6 \mathrm{I}$ & $3.5 \mathrm{R}$ & 0.40 \\
\hline USPT-CBB-1 & Pyr & SAP6 & $2.6 \mathrm{R}$ & $5.4 \mathrm{I}$ & $5.0 \mathrm{I}$ & $2.5 \mathrm{R}$ & $3.0 \mathrm{R}$ & $4.3 \mathrm{I}$ & $4.7 \mathrm{I}$ & $4.6 \mathrm{I}$ & $4.0 \mathrm{I}$ & 0.32 \\
\hline OAC Rex & $\mathrm{Pa}$ & SU91 & $3.3 \mathrm{R}$ & $3.8 \mathrm{R}$ & $3.5 \mathrm{R}$ & $2.1 \mathrm{R}$ & $\underline{4.2 \mathrm{I}}$ & $2.9 \mathrm{R}$ & $3.1 \mathrm{R}$ & $2.7 \mathrm{R}$ & $3.2 \mathrm{R}$ & 0.28 \\
\hline OAC 88-1 & $\mathrm{Pa}$ & SAP6+SU91 & $3.9 \mathrm{R}$ & $4.0 \mathrm{I}$ & $3.1 \mathrm{R}$ & $2.3 \mathrm{R}$ & $\overline{4.5 \mathrm{I}}$ & $2.7 \mathrm{R}$ & $2.9 \mathrm{R}$ & $2.8 \mathrm{R}$ & $3.3 \mathrm{R}$ & 0.30 \\
\hline USPT-CBB-5 & Pyr & SAP6+SU91 & $3.5 \mathrm{R}$ & $4.9 \mathrm{I}$ & $4.2 \mathrm{I}$ & $3.0 \mathrm{R}$ & $3.0 \mathrm{R}$ & $4.4 \mathrm{I}$ & $3.8 \mathrm{R}$ & $4.3 \mathrm{I}$ & $3.9 \mathrm{R}$ & 0.32 \\
\hline VAX 3 & Pyr & SAP6+SU91 & $2.2 \mathrm{R}$ & $2.3 \mathrm{R}$ & $2.0 \mathrm{R}$ & $2.0 \mathrm{R}$ & $2.0 \mathrm{R}$ & $2.3 \mathrm{R}$ & $2.3 \mathrm{R}$ & $2.5 \mathrm{R}$ & $2.2 \mathrm{R}$ & 0.27 \\
\hline VAX 4 & Pyr & SAP6+SU91 & $2.1 \mathrm{R}$ & $2.3 \mathrm{R}$ & $2.0 \mathrm{R}$ & $2.0 \mathrm{R}$ & $2.6 \mathrm{R}$ & $2.5 \mathrm{R}$ & $2.4 \mathrm{R}$ & $2.5 \mathrm{R}$ & $2.3 \mathrm{R}$ & 0.36 \\
\hline VAX 5 & Pyr & SAP6+SU91 & $2.0 \mathrm{R}$ & $3.1 \mathrm{R}$ & $2.5 \mathrm{R}$ & $2.0 \mathrm{R}$ & $2.2 \mathrm{R}$ & $2.5 \mathrm{R}$ & $2.5 \mathrm{R}$ & $2.8 \mathrm{R}$ & $2.4 \mathrm{R}$ & 0.55 \\
\hline VAX 6 & Pyr & SAP6+SU91 & $2.3 \mathrm{R}$ & $2.6 \mathrm{R}$ & $2.3 \mathrm{R}$ & $2.4 \mathrm{R}$ & $2.8 \mathrm{R}$ & $2.3 \mathrm{R}$ & $2.4 \mathrm{R}$ & $2.7 \mathrm{R}$ & $2.5 \mathrm{R}$ & 0.32 \\
\hline XAN 309 & Pyr & SAP6+SU91 & $2.4 \mathrm{R}$ & $2.9 \mathrm{R}$ & $2.4 \mathrm{R}$ & $2.0 \mathrm{R}$ & $2.3 \mathrm{R}$ & $3.0 \mathrm{R}$ & $3.1 \mathrm{R}$ & $2.9 \mathrm{R}$ & $2.6 \mathrm{R}$ & 0.32 \\
\hline XAN 159 & $\mathrm{~Pa}$ & SU91+BC420 & $2.9 \mathrm{R}$ & $3.6 \mathrm{R}$ & $3.0 \mathrm{R}$ & $2.5 \mathrm{R}$ & $3.2 \mathrm{R}$ & $2.8 \mathrm{R}$ & $2.5 \mathrm{R}$ & $3.0 \mathrm{R}$ & $2.9 \mathrm{R}$ & 0.28 \\
\hline Wilkinson 2 & Pyr & SU91+BC420 & $3.3 \mathrm{R}$ & $3.6 \mathrm{R}$ & $3.4 \mathrm{R}$ & $2.5 \mathrm{R}$ & $3.3 \mathrm{R}$ & $3.0 \mathrm{R}$ & $2.7 \mathrm{R}$ & $3.0 \mathrm{R}$ & $3.1 \mathrm{R}$ & 0.40 \\
\hline HR 45 & Pyr & All three & $2.8 \mathrm{R}$ & $3.3 \mathrm{R}$ & $2.8 \mathrm{R}$ & $2.0 \mathrm{R}$ & $2.8 \mathrm{R}$ & $2.4 \mathrm{R}$ & $2.7 \mathrm{R}$ & $3.0 \mathrm{R}$ & $2.7 \mathrm{R}$ & 0.40 \\
\hline Strain Mean & $\ldots$ & $\ldots$ & 3.7 & 5.2 & 4.7 & 2.6 & 3.3 & 4.5 & 4.3 & 4.8 & 4.1 & 0.33 \\
\hline $\operatorname{LSD}(P=0.05)$ & $\ldots$ & $\ldots$ & 0.43 & 0.46 & 0.38 & 0.42 & 0.44 & 0.46 & 0.38 & 0.41 & 0.48 & $\ldots$ \\
\hline
\end{tabular}

a Experiments were conducted in a greenhouse at the University of California, Davis in 2007. Results represent means of two independent experiments.

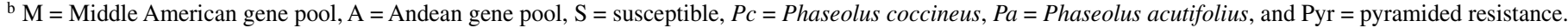

${ }^{c}$ Data based on the 1 -to-9 rating scale, where $1<4=$ resistant $(\mathrm{R}), 4<7=$ intermediate (I), and $7-9=$ susceptible $(\mathrm{S})$.

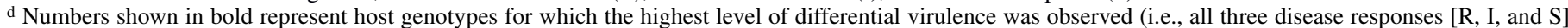

were observed). Underlined numbers show common bean genotypes that differentiated the East African X. campestris pv. phaseoli genotypes (M11 and T21).

e Least significant difference (LSD) $(P=0.05)$. 
had resistance introgressed from Middle-American sources and had SAP6 or no markers (Table 4).

Genotypes with only the SAP6 marker varied considerably in their response to the pathogen genotypes tested. For example, VAX 1, VAX 2, G 17341, and G 17344 had resistant or intermediate responses to most strains, whereas ICB 11 and ICB 67 had susceptible or intermediate responses (Table 4). In addition, some host genotypes with no markers had resistant or intermediate responses to all strains (e.g., G 1320 [PI 207062], XAN 91, and ICB 53) (Table 4).

A highly significant $(P<0.01)$ host-pathogen interaction was detected in this study, which is fully consistent with the variation in virulence observed for the common blight bacteria. A number of host genotypes revealed evidence of specificity, which is defined as $>3$ point difference in DSI values for response to specific $X$. campestris pv. phaseoli or $X$. fuscans subsp. fuscans genotypes, and these included Chase, Montcalm, TARS VCI-4B, and ICB 67. These genotypes all had the SAP6 marker. Other host genotypes were resistant to some pathogen genotypes but had intermediate responses to others. These included genotypes with the SAP6 marker (Colima 9 and G 1320), resistance introgressed from $P$. acutifolius (OAC Rex and OAC 88-1), or pyramided resistance (G 17341, G 17344, and USPT-CBB-5). Consistent with the significant host-pathogen interaction, the relative order of the host genotypes, from most resistant to most susceptible, varied depending on the pathogen genotype. For example, the host order was different for $X$. campestris pv. phaseoli strains PR1 and Xcp25 (Table 4, ranking not shown).

\section{DISCUSSION}

$\mathrm{CBB}$ is an economically important disease of DRK bean in the Midwestern United States, and can cause substantial losses in yield and quality. However, the severity of CBB was low to moderate in the central Wisconsin DRK bean fields surveyed in 2005 and 2006, most likely reflecting unfavorable climatic conditions and the planting of pathogen-free seed. In fact, identification of CBB symptoms in some fields was complicated by the abiotic pseudo-CBB symptoms, which develop due to heat and water stress. Diagnosis of $\mathrm{CBB}$ was confirmed by isolation of xanthomonad-like bacteria on the semiselective medium MXP, but this was complicated by the presence of nonpathogenic xanthomonads. These xanthomonads were previously reported associated with common bean in Wisconsin and other beangrowing regions $(2,12,15)$, and must be differentiated from common blight bacteria by genetic or pathogenicity tests. Together, these results highlight the need to perform Koch's postulates to confirm CBB diagnoses in certain field situations.

The majority of common blight bacteria associated with CBB in DRK bean in central Wisconsin were $X$. campestris $\mathrm{pv}$. phaseoli. This supports the hypothesis that $X$. campestris pv. phaseoli strains are most commonly associated with $\mathrm{CBB}$ in large-seeded Andean genotypes $(23,34)$. Interestingly, the $X$. campestris pv. phaseoli population was not clonal because two $X$. campestris pv. phaseoli phenotypes/genotypes were involved: typical $X$. campestris pv. phaseoli strains with yellow mucoid colonies, no brown pigment production, and $X$. campestris pv. phaseoli-type rep-PCR fingerprints; and the new Px X. campestris pv. phaseoli strains, with a less mucoid and flatter colony, brown pigment production, and $X$. campestris pv. phaseoli-type rep-PCR fingerprints. Initially, the Px strains were thought to be $X$. fuscans subsp. fuscans, based on colony morphology and brown pigment production; however, genetic analyses clearly showed that they were $X$. campestris pv. phaseoli strains. Moreover, the Px strains play an important role in CBB in this region, because they were commonly isolated and are highly virulent. Finally, the fact that these two $X$. campestris pv. phaseoli phenotypes/genotypes did not seem to coexist in most fields may indicate competition, and it will be of interest to see whether the population structure changes in the future and whether $\mathrm{Px} X$. campestris pv. phaseoli strains are identified in other geographic regions.

Brown pigment production is a distinctive characteristic of $X$. fuscans subsp. fuscans strains. Thus, the discovery of a brownpigmented strain of $X$. campestris pv. phaseoli was unexpected and revealed phenotypic variability among strains of this bacterium. However, brown pigment production did not enhance virulence, because strain Px100 was slightly less virulent than Xcp25, which has a similar rep-PCR fingerprint but does not produce brown pigment (Table 4). It may enhance bacterial fitness in some other way, such as epiphytic survival. It would be interesting to determine the genetic basis of brown pigment production in the $\mathrm{Px} X$. campestris pv. phaseoli strains, because they produced substantially less brown pigment than $X$. fuscans subsp. fuscans strains. This may reflect horizontal gene transfer between X. campestris pv. phaseoli and X. fuscans subsp. fuscans or the activation of an existing biosynthetic pathway, perhaps via a mobile genetic element (13). Finally, these results raise some concerns about using brown pigment production to differentiate $X$. campestris pv. phaseoli and X. fuscans subsp. fuscans strains.

The East African $X$. campestris pv. phaseoli genotypes (represented by M11 and T21) were substantially less virulent than typical $X$. campestris pv. phaseoli strains, which is consistent with previous reports $(23,34)$. Moreover, the results of the rep-PCR and spacer region sequence analyses performed in the present study indicated that these genetically distinct East African $X$. campestris pv. phaseoli strains were more closely related to $X$. fuscans subsp. fuscans than $X$. campestris pv. phaseoli. This raises the possibility that $X$. fuscans subsp. fuscans strains may have originated in Africa, and is consistent with the frequent association of $X$. fuscans subsp. fuscans with CBB in East Africa (35). Thus, our results extend the idea that common blight bacteria are a heterogeneous polyphetic group of xanthomonads, which include one or more genotypes or species that have probably evolved independently. Similar findings have been reported for xanthomonads causing bacterial spot disease of tomato $(17,18)$ and black rot of crucifers $(14,26,52)$.

The finding that $X$. campestris pv. phaseoli strains were more variable in virulence than $X$. fuscans subsp. fuscans strains is in agreement with results of Mutlu et al. (36). However, unlike our findings, Mutlu et al. (36) found that X. fuscans subsp. fuscans strains were more virulent than $X$. campestris pv. phaseoli strains, regardless of geographic origin. This may be explained by the different pathogen strains used in the respective studies. Nonetheless, the substantial variability in virulence among common blight bacteria revealed in the present study and those of others $(23,34,36)$ has practical significance in terms of selecting the appropriate $X$. campestris pv. phaseoli or $X$. fuscans subsp. fuscans strains for $\mathrm{CBB}$ resistance breeding. Use of less virulent strains (e.g., the East African X. campestris pv. phaseoli strains) or strains with attenuated virulence due to repeated subculturing can lead to selection of "resistant" common bean genotypes that have susceptible or intermediate responses to more virulent strains. For example, a number of common bean genotypes with the SAP6 marker were resistant to the PR1 X. campestris pv. phaseoli strain but susceptible to the Xcp25 strain; thus, genotypes bred for resistance to PR1 would be susceptible to strains such as Xcp25. This situation may explain why a recently released CBB-resistant DRK breeding line (USDK-CBB-15) was not resistant under high levels of $\mathrm{CBB}$ pressure in the field in Wisconsin or when inoculated with the highly virulent Xcp25 (22).

The only known source of CBB resistance from common bean is a QTL derived from Middle-American genotypes that is linked with the SAP6 marker (28). However, some genotypes with only the SAP6 marker were susceptible to some pathogen genotypes, 
indicating that SAP6-associated resistance is not sufficient for effective $\mathrm{CBB}$ management or that the resistance is not sufficiently closely linked to the marker. The most robust CBB resistance has been introgressed from $P$. acutifolius (via XAN 159) and is associated with the SU91 marker (49). Thus, our finding that all of the most resistant common bean genotypes had this marker is fully consistent with these results (51). However, the highest levels of resistance were associated with genotypes with pyramided resistance (SU91 and one or both of the other markers), indicating that introgression of appropriate combinations of CBB resistance QTL, via marker-assisted selection, can result in genotypes with broad-spectrum resistance to a diversity of pathogen genotypes. This is consistent with other studies, and we are in agreement with Mutlu et al. (36) and Lema et al. (22) that only genotypes with pyramided resistance should be developed and deployed in common bean-production regions where CBB is prevalent $(23,25,37)$. Moreover, having pyramided resistance available in diverse backgrounds (e.g., VAX 3, VAX 4, VAX 5, VAX 6, Wilkinson 2, XAN 159, and XAN 309) should allow for incorporation of $\mathrm{CBB}$ resistance into all market classes, including large-seeded Andean cultivars, such as DRK bean. Finally, a strategy based upon multiple QTL should provide more durable resistance than that conferred by single dominant or recessive resistance genes. This is important, because it is clear that multiple pathogen genotypes can exist together in a region or an individual field (Table 1), which could allow for exchange of genetic material among strains and emergence of resistancebreaking strains.

However, it is important to note that genotypes with pyramided resistance varied in levels of $\mathrm{CBB}$ resistance and that some genotypes, such as USDK-CBB-15 with the SAP6 and SU91 markers, may be susceptible under high disease pressure (22). This indicates that pyramided resistance does not necessarily confer high levels of resistance in all cases, and highlights the need to use appropriate pathogen strains in $\mathrm{CBB}$ resistance breeding. Another potential problem is that the SU91 marker has been associated with a reduction in yield (37). This may complicate its use in $\mathrm{CBB}$ resistance-breeding programs unless such undesirable linkages could be broken. Alternatively, additional sources of $\mathrm{CBB}$ resistance (and associated markers) could be used. Indeed, our results also indicated the presence of unmarked CBB resistance QTL in some of the common bean genotypes tested based on the variation in response of genotypes with similar marker compositions to certain pathogen genotypes (Table 4). These results are also consistent with the quantitative nature of $\mathrm{CBB}$ resistance in common bean, and the identification of CBB resistance QTL on all the common bean linkage groups $(22,29)$.

In conclusion, we confirmed the association of $X$. campestris pv. phaseoli with CBB in a major production area of large-seeded Andean bean (DRK) and revealed new phenotypic variability in $X$. campestris pv. phaseoli with the identification of a brownpigmented phenotype and genotype. This extends the concept that common blight bacteria are a heterogeneous group of xanthomonads, and highlights the importance of selecting appropriate pathogen strains for resistance-breeding programs. Our results also support the hypothesis that common bean genotypes with multiple introgressed CBB resistance QTL can be highly resistant to a diversity of common blight bacteria. These genotypes can be used for the development of CBB-resistant common bean cultivars in multiple market classes.

\section{ACKNOWLEDGMENTS}

This research was supported in part by Chippewa Valley Bean Co. and Pioneer Hi-Bred International, Inc., through The Pioneer Hi-Bred International, Inc. Fellowship in Plant Pathology to R. W. Duncan. We thank P. Gepts for his thoughtful review of this manuscript and N. Hakimi for excellent technical assistance.

\section{LITERATURE CITED}

1. Alavi, S. M., Sanjari, S., Durand, F., Brin, C., Manceau, C., and Poussier, S. 2008. Assessment of the genetic diversity of Xanthomonas axonopodis pv. phaseoli and Xanthomonas fuscans subsp. fuscans as a basis to identify putative pathogenicity genes and a type III secretion system of the SPI-1 family by multiple suppression subtractive hybridizations. Appl. Environ. Microbiol. 74:3295-3301.

2. Angelesramos, R., Vidaver, A. K., and Flynn, P. 1991. Characterization of epiphytic Xanthomonas campestris pv. phaseoli and pectolytic xanthomonads recovered from symptomless weeds in the Dominican Republic. Phytopathology 81:677-681.

3. Audy, P., Laroche, A., Saindon, G., Huang, H. C., and Gilbertson, R. L. 1994. Detection of the bean common blight bacteria, Xanthomonas campestris pv. phaseoli and X. campestris phaseoli var. fuscans, using the polymerase chain-reaction. Phytopathology 84:1185-1192.

4. Barak, J. D., and Gilbertson, R. L. 2003. Genetic diversity of Xanthomonas campestris pv. vitians, the causal agent of bacterial leafspot of lettuce. Phytopathology 93:596-603.

5. Birch, P. R. J., Hyman, L. J., Taylor, R., Opio, A. F., Bragard, C., and Toth, I. K. 1997. RAPD PCR-based differentiation of Xanthomonas campestris pv. phaseoli and Xanthomonas campestris pv. phaseoli var. fuscans. Eur. J. Plant Pathol. 103:809-814.

6. Chan, J. W. Y. F., and Goodwin, P. H. 1999. Differentiation of Xanthomonas campestris pv. phaseoli from Xanthomonas campestris pv. phaseoli var. fuscans by PFGE and RFLP. Eur. J. Plant Pathol. 105:867878.

7. Claflin, L. E., Sasser, M. D., and Vidaver, A. K. 1987. MXP, a semiselective medium for Xanthomonas campestris pv. phaseoli. Phytopathology 77:730-734.

8. Dellaporta, S. L., Wood, J., and Hicks, J. B. 1983. A plant DNA minipreparation: Version II. Plant Mol. Biol. Rep. 1:19-21.

9. Duncan, R. W., Lema, M., Singh, S. P., and Gilbertson, R. L. 2007. Linkage between a Xanthomonas campestris pv. phaseoli resistance SCAR marker and flower and seed color in common bean. (Abstr.) Phytopathology 97:S30.

10. Gilbertson, R. L., and Maxwell, D. P. 1992. Common blight of bean. In: Diseases of International Importance. H. S. Chaube, U. S. Singh, and A. N. Mukhopadhay, eds. Prentice Hall, Inglewood Cliffs, NJ.

11. Gilbertson, R. L., Maxwell, D. P., Hagedorn, D. J., and Leong, S. A. 1989. Development and application of a plasmid DNA probe for detection of bacteria causing common bacterial blight of bean. Phytopathology 79:518-525.

12. Gilbertson, R. L., Rand, R. E., and Hagedorn, D. J. 1990. Survival of Xanthomonas campestris pv. phaseoli and pectolytic strains of $X$. campestris in bean debris. Plant Dis. 74:322-327.

13. Goodwin, P. H., and Sopher, C. R. 1994. Brown pigmentation of Xanthomonas campestris pv. phaseoli associated with homogentisic acid. Can. J. Microbiol. 40:28-34.

14. Ignatov, A., Sechler, A., Schuenzel, E. L., Agarkova, I., Oliver, B., Vidaver, A. K., and Schaad, N. W. 2007. Genetic diversity in populations of Xanthomonas campestris pv. campestris in cruciferous weeds in central coastal California. Phytopathology 97:803-812.

15. Ishimaru, C., Eskridge, K. M., and Vidaver, A. K. 1991. Distribution analyses of naturally occurring epiphytic populations of Xanthomonas campestris pv. phaseoli on dry beans. Phytopathology 81:262-268.

16. Jensen, M. A., Webster, J. A., and Straus, N. 1993. Rapid identification of bacteria on the basis of polymerase chain reaction-amplified ribosomal DNA spacer polymorphisms. Appl. Environ. Microbiol. 59:945-952.

17. Jones, J. B., Lacy, G. H., Bouzar, H., Stall, R. E., and Schaad, N. W. 2004. Reclassification of the xanthomonads associated with bacterial spot disease of tomato and pepper. Syst. Appl. Microbiol. 27:755-762.

18. Jones, J. B., Stall, R. E., and Bouzar, H. 1998. Diversity among xanthomonads pathogenic on pepper and tomato. Annu. Rev. Phytopathol. 36:41-58.

19. Kado, C. I., and Heskett, M. G. 1970. Selective media for isolation of Agrobacterium, Corynebacterium, Erwinia, Pseudomonas, and Xanthomonas. Phytopathology 60:969-976.

20. Koike, S. T., Barak, J. D., Henderson, D. M., and Gilbertson, R. L. 1999. Bacterial blight of leek: A new disease in California caused by Pseudomonas syringae. Plant Dis. 83:165-170.

21. Kumar, S., Nei, M., Dudley, J., and Tamura, K. 2008. MEGA: A biologistcentric software for evolutionary analysis of DNA and protein sequences. Brief. Bioinf. 9:299-306.

22. Lema, M., Terán, H., and Singh, S. P. 2007. Selecting common bean with genes of different evolutionary origins for resistance to Xanthomonas campestris pv. phaseoli. Crop Sci. 47:1367-1374.

23. Lopez, R., Asensio, C., and Gilbertson, R. L. 2006. Phenotypic and genetic diversity in strains of common blight bacteria (Xanthomonas campestris pv. phaseoli and X. campestris pv. phaseoli var. fuscans) in a 
secondary center of diversity of the common bean host suggests multiple introduction events. Phytopathology 96:1204-1213.

24. Louws, F. J., Fulbright, D. W., Stephens, C. T., and Debruijn, F. J. 1994. Specific genomic fingerprints of phytopathogenic Xanthomonas and Pseudomonas pathovars and strains generated with repetitive sequences and PCR. Appl. Environ. Microbiol. 60:2286-2295.

25. Mahuku, G. S., Jara, C., Henriquez, M. A., Castellanos, G., and Cuasquer, J. 2006. Genotypic characterization of the common bean bacterial blight pathogens, Xanthomonas axonopodis pv. phaseoli and Xanthomonas axonopodis pv. phaseoli var. fuscans by rep-PCR and PCR-RFLP of the ribosomal genes. J. Phytopathol. 154:35-44.

26. Massomo, S. M. S., Nielsen, H., Mabagala, R. B., Mansfeld-Giese, K., Hockenhull, J., and Mortensen, C. N. 2003. Identification and characterisation of Xanthomonas campestris pv. campestris strains from Tanzania by pathogenicity tests, Biolog, rep-PCR and fatty acid methyl ester analysis. Eur. J. Plant Pathol. 109:775-789.

27. McElroy, J. B. 1985. Breeding for dry beans, P. vulgaris L., for common bacterial blight resistance derived from Phaseolus acutifolius A. Gray. Ph.D. dissertation, Cornell University, Ithaca, NY.

28. Miklas, P. N., Coyne, D. P., Grafton, K. F., Mutlu, N., Reiser, J., Lindgren, D. T., and Singh, S. P. 2003. A major QTL for common bacterial blight resistance derives from the common bean great northern landrace cultivar Montana No. 5. Euphytica 131:137-146.

29. Miklas, P. N., Kelly, J. D., Beebe, S. E., and Blair, M. W. 2006. Common bean breeding for resistance against biotic and abiotic stresses: From classical to MAS breeding. Euphytica 147:105-131.

30. Miklas, P. N., Smith, J. R., Riley, R., Grafton, K. F., Singh, S. P., Jung, G., and Coyne, D. P. 2000. Marker-assisted breeding for pyramided resistance to common bacterial blight in common bean. Annu. Rep. Bean Improv. Coop. 43:39-40.

31. Miklas, P. N., Smith, J. R., and Singh, S. P. 2006. Registration of common bacterial blight resistant dark red kidney bean germplasm line USDKCBB-15. Crop Sci. 46:1005-1007.

32. Miklas, P. N., Smith, J. R., and Singh, S. P. 2006. Registration of common bacterial blight resistant white kidney bean germplasm line USWK-CBB17. Crop Sci. 46:2338-2339.

33. Miklas, P. N., Zapata, M., Beaver, J. S., and Grafton, K. F. 1994. Registration of four dry bean germplasm resistant to common bacterial blight: ICB-3, ICB-6, ICB-8, ICB-10. Crop Sci. 39:594.

34. Mkandawire, A. B. C., Mabagala, R. B., Guzman, P., Gepts, P., and Gilbertson, R. L. 2004. Genetic diversity and pathogenic variation of common blight bacteria (Xanthomonas campestris pv. phaseoli and $X$. campestris pv. phaseoli var. fuscans) suggests pathogen coevolution with the common bean. Phytopathology 94:593-603.

35. Mutlu, N., Coyne, D. P., Steadman, J. R., Reiser, J., and Sutton, L. 2002. Progress in a backcross breeding with RAPD (SCAR) molecular markers to pyramid QTLs for resistance to common bacterial blight in pinto and great northern beans. Annu. Rep. Bean Improv. Coop. 45:70-71.

36. Mutlu, N., Vidaver, A. K., Coyne, D. P., Steadman, J. R., Lambrecht, P. A., and Reiser, J. 2008. Differential pathogenicity of Xanthomonas campestris pv. phaseoli and X. fuscans subsp. fuscans strains on bean genotypes with common blight resistance. Plant Dis. 92:546-554.

37. O'Boyle, P. D., Kelly, J. D., and Kirk, W. W. 2007. Use of marker-assisted selection to breed for resistance to common bacterial blight in common bean. HortScience 132:381-386.

38. Opio, A. F., Allen, D. J., and Teri, J. M. 1995. The role of weeds and nonhost crops in the survival of Xanthomonas campestris pv. phaseoli in Uganda. Annu. Rep. Bean Improv. Coop. 38:166-167.

39. Park, S. J., and Dhanvantari, B. N. 1987. Transfer of common blight (Xanthomonas campestris pv. phaseoli) resistance from Phaseolus coccineus Lam. to $P$. vulgaris L. through interspecific hybridization. Can. J. Plant Sci. 67:685-695.

40. Parker, J. P., and Michaels, T. E. 1986. Simple genetic control of hybrid plant development in interspecific crosses between Phaseolus vulgaris L. and Phaseolus acutifolius A. Gray. Plant Breed. 97:315-323.

41. Pastor-Corrales, M. A., Beebe, S. E., and Correa, F. J. 1981. Comparing 2 inoculation techniques for evaluating resistance in beans to Xanthomonas campestris pv. phaseoli. In: Fifth Int. Conf. Plant Pathogenic Bacteria. C. J. Lozano, ed. CIAT, Cali, Colombia.

42. Pedraza, F., Gallego, G., Beebe, S. E., and Tohme, J. 1997. Marcadores SCAR y RAPD para la resistencia a la bacteriosis comun (CBB). In: Taller de mejoramiento de frijol para el Siglo XXI: Bases para una estrategia para America Latina. S. P. Singh and O. Voysest, eds. CIAT, Cali, Colombia.

43. Rademaker, J. L. W., and de Bruijn, F. J. 1997. Characterization and classification of microbes by rep-PCR genomic fingerprinting and computer assisted pattern analysis. In: DNA Markers: Protocols, Applications and Overviews. G. Cactano-Anolles and P. M. Gresshoff, eds. John Wiley \& Sons, New York.

44. Rademaker, J. L. W., Louws, F. J., Schultz, M. H., Rossbach, U., Vauterin, L., Swings, J., and de Bruijn, F. J. 2005. A comprehensive species to strain taxonomic framework for Xanthomonas. Phytopathology 95:1098-1111.

45. Saettler, A. W. 1989. Common bacterial blight. In: Bean Production Problems in the Tropics. H. F. Schwartz and M. A. Pastor-Corrales, eds. CIAT, Cali, Colombia.

46. Saettler, A. W., Cafati, C. R., and Weller, D. M. 1986. Nonoverwintering of Xanthomonas bean blight bacteria in Michigan. Plant Dis. 70:285-287.

47. Schaad, N. W., Postnikova, E., Lacy, G. H., Sechler, A., Agarkova, I., Stromberg, P. E., Stromberg, V. K., and Vidaver, A. K. 2005 Reclassification of Xanthomonas campestris pv. citri (ex Hasse 1915) Dye 1978 forms A, B/C/D, and E as X. smithii subsp. citri (ex Hasse) sp. nov. nom. rev. comb. nov., $X$. fuscans subsp. aurantifolii (ex Gabriel 1989) sp. nov. nom. rev. comb. nov., and X. alfalfae subsp. citrumelo (ex Riker and Jones) Gabriel et al., 1989 sp. nov. nom. rev. comb. nov.; $X$ campestris pv. malvacearum (ex Smith 1901) Dye 1978 as X. smithii subsp. smithii nov. comb. nov. nom. nov.; $X$. campestris pv. alfalfae (ex Riker and Jones, 1935) Dye 1978 as X. alfalfae subsp. alfalfae (ex Riker et al., 1935) sp. nov. nom. rev.; and "var. fuscans" of X. campestris pv. phaseoli (ex Smith, 1987) Dye 1978 as X. fuscans subsp. fuscans sp. nov. Syst. Appl. Microbiol. 28:494-518.

48. Schuster, M. L., and Coyne, D. P. 1981. Biology, epidemiology, genetics and breeding for resistance to bacterial pathogens of Phaseolus vulgaris L. Hortic. Rev. 3:28-57.

49. Singh, S. P., and Muñoz, C. G. 1999. Resistance to common bacterial blight among Phaseolus species and common bean improvement. Crop Sci. 39:80-89.

50. Thompson, J. D., Higgins, D. G., and Gibson, T. J. 1994. CLUSTAL W: Improving the sensitivity of progressive multiple sequence alignment through sequence weighting, position-specific gap penalties and weight matrix choice. Nucleic Acids Res. 22:4673-4680.

51. Vandemark, G. J., Fourie, D., and Miklas, P. N. 2008. Genotyping with real-time PCR reveals recessive epistasis between independent QTL conferring resistance to common bacterial blight in dry bean. Theor. Appl. Genet. 117:513-522.

52. Vicente, J. G., Conway, J., Roberts, S. J., and Taylor, J. D. 2001 Identification and origin of Xanthomonas campestris pv. campestris races and related pathovars. Phytopathology 91:492-499.

53. Yu, K., Park, S. J., and Poysa, V. 2000. Marker-assisted selection of common beans for resistance to common bacterial blight: Efficacy and economics. Plant Breed. 119:411-415. 